\title{
Student Teaching in Diverse Settings
}

\author{
Adem BAYAR* \\ Department of Educational Science, College of Education, Amasya University, Turkey
}

\begin{tabular}{|c|c|}
\hline \multicolumn{2}{|c|}{ Curriculum Studies, School of Education, Indiana University, USA } \\
\hline Article history & This study explores the cases of teachers who had overseas field \\
\hline $\begin{array}{l}\text { Received: } \\
29.12 .2014\end{array}$ & $\begin{array}{l}\text { experience. In this study, it is aimed at hearing what teachers say } \\
\text { about their experiences and announce their reflections for others in }\end{array}$ \\
\hline $\begin{array}{l}\text { Received in revised form: } \\
01.07 .2015\end{array}$ & $\begin{array}{l}\text { order to contribute others' learning that have not had cross-cultural } \\
\text { experiences. In order to reach the aim of this study, the researchers }\end{array}$ \\
\hline Accepted: & have addressed the following research questions throughout this \\
\hline 22.07.2015 & $\begin{array}{l}\text { research: } 1 \text {. Do participants perceive cross-cultural teaching as an } \\
\text { aid to self- development?, } 2 \text {. Do participants believe overseas }\end{array}$ \\
\hline Key words: & experiences lead them to gain global perspectives?, and 3 . What \\
\hline $\begin{array}{l}\text { Teacher, overseas experiences, } \\
\text { diversity, teacher education. }\end{array}$ & $\begin{array}{l}\text { kind of learning has occurred within overseas experiences? In order } \\
\text { to grasp the feelings and ideas of the teachers, semi-structure } \\
\text { interview has been used. The respondent group of this study is four } \\
\text { teachers. The findings of this current study obviously reveal that } \\
\text { the participant teachers have benefited positively as a result of } \\
\text { overseas experiences. These benefits include both personal and } \\
\text { professional development. The participant teachers explained that } \\
\text { they have learned much about instructional methodology, how to } \\
\text { access children, and various classroom management styles based } \\
\text { upon interaction with teachers in host nations and classroom } \\
\text { observations. Also, by living in a different country, the participant } \\
\text { teachers have reported that they have learned first-hand information } \\
\text { about culture, tradition, folklore, history, and social condition of } \\
\text { host nations. Learning these experiences help them, as teachers, to } \\
\text { gain a meaningful perspective on other cultures, figure out the } \\
\text { deepest ideas, assumptions, ideologies, which create that culture } \\
\text { and it allows being aware of their own place in the world. }\end{array}$ \\
\hline
\end{tabular}

\section{Introduction}

In recent years, teachers have been under the siege about the ways in which they meet the needs of diverse learners. While schools have become more varied, nations have been under the influence of globalization processes. One of the questions in the arena of teacher education regards the ways that teachers should be prepared to teach in a diverse and complex world. Schools are full of diverse learners, yet most of teachers have limited exposure to

\footnotetext{
Correspondence: adembayar80@gmail.com
} 
cultural diversity and a little knowledge of the world (O'Connor \& Zeichner, 2011). Additionally teachers are unaware of influence of globalization on the life of a child (Grant, 1992; Ladson-Billings, 1994; Merryfield, 1991). In order to fill this gap, many universities in the United States have initiated cross-cultural teacher education programs to prepare preservice teachers for diverse teaching environments and a complex world. Some scholars support the claim that having international or cross-cultural experiences may help teachers to live with harmony in diverse groups (Ference \& Bell, 2004; Pence \& Macgillivray, 2008; Wilson, 1982).

In this study, the researchers have explored experiences and cases of teachers who participated overseas student teaching project. Starting from the Eisner (1991) claim that the voices of teachers are very important sources in educational research. Thus, the researchers have aimed to hear what teachers state about their personal experiences and announce their reflections for others in order to contribute others that have not had cross-cultural experiences. Also, the results of this study are beneficial for curriculum designers, and teacher educators to provide and design field experiences with active engagement for prospective teachers.

\section{Literature Review}

The importance of overseas cultural immersion experiences has already been discussed in numerous studies (Barkhuizen \& Feryok, 2006; Ference \& Bell, 2004; Pence \& Macgillivray, 2008; Stachowski \& Sparks, 2007; Wilson, 1982). Previous studies indicate that overseas experiences help teachers to grow in both personal and professional life. First of all, international teaching experiences allow teachers to gain self-awareness "who they are" and to understand values and beliefs which underpin their teaching. Cushner (2007) asserts that "The experience abroad, regardless of the level at which it takes place, offers the individual a unique opportunity for intercultural development as it involves both physical and psychological transitions that engage the cognitive, affective, and behavioral domains" (p. 29). In particular, living with host families leads to learn more about culture, tradition, history, and social condition of host nations. Stachowski and Mahan (1995) claim that as the relationships with the host family develop, information about respective cultures is shared, stereotypes are dissolved and differences in lifestyle are examined and potentially adopted.

Having international experiences enable teachers to develop empathy and patience, enhance their multicultural understanding and made them "less prone to prejudge students based on cultural background, linguistic difference, or even learning disability" (Willard-Holt, 2001, p. 515). They become more mature, and begin to question their stereotypes of others as well as aspects of their own culture which had previously been unexamined (Cushner, 2007).

International field experiences also play an important role in preparing pre-service teachers as citizens of the global world (Mahan \& Stachowski, 1995). Through these experiences students are able to see what happened in other countries, and how they educate their children. After engaging in international context, students became more vulnerable towards global issues such as poverty, peace, racism, equity, and increase their level of cultural sensitivity.

The framework of this study is draw upon Wilson's (1993) model on international education. According to this model, an internationally experienced individual can gain a global perspective, including substantive knowledge and perceptual understanding. Also, based upon this model, international experiences often lead to personal growth and new interpersonal relationships. Within this framework, the research questions of this study are following: 1. Do participants perceive cross-cultural teaching as an aid to self- development?, 2. Do 
participants believe overseas experiences lead them to gain global perspectives?, and 3. What kind of learning has occurred within overseas experiences?

\section{Methodology}

The researchers have employed a qualitative research approach in this study. Since, the researchers have aimed to get in-depth information about topic. In this regard, some researchers have claimed that using qualitative research approach is the best way for getting detailed data (Lichtman, 2013; Mertens, 2009; Taylor \& Bogdan, 1998). For this aim, the researchers, first, have employed document analysis technique by analyzing the description, curriculum materials, structures, and syllabus of the program. Following, the researchers have conducted semi-structured interview with the participants. The respondent group for this study consists of 4 volunteer teachers who participated in an overseas student teaching project at one of the mid-west university in the United States. Two participants went to Scotland; one went to New Zealand, and the last one went to England. The participants first took intensive preparation prior to going abroad. During the preparation process, they were taught about their host country/nation's living condition, culture, history, and education system. Then, they were assigned for their host nations' schools.

When the participants returned to their home, they were interviewed to gain deep understanding about their experiences. The semi-structured interview was the main instrument of this study; in this way "some questions will be developed in advance with follow-up questions on the spotlight of participants' responses" (Patton, 2010, p. 77). Interviewees were given the flexibility to expressing their ideas, opinions and concerns. The participants are interviewed face to face and one time. Each interview lasted approximately 45 minutes. After receiving permission from participants, each interview session was recorded and transcribed. By doing so, the researchers have collected the data about the participants' first-hand experience with their own overseas field experience. After gathering all data, the researchers have analyzed them based on descriptive viewpoint. At this point, the researchers have first determined the codes; next developed categories via merging the codes. Afterwards, the researchers have combined similar categories and finally gotten the themes. The researchers have additionally profited from the previous studies in the literature for naming the themes. Subsequently, the researchers have gotten some of the participants' speeches to the study as citation and/or quotation. In order to increase the reliability and validity of the data analysis procedure, the researchers have used "adequate engagement in data collection", and "rich, thick descriptions" strategies (Merriam, 2009). Some of the semi-structure interview questions have been shown below:

- What is your purpose to participate in overseas student teaching project?

- What are the advantages and disadvantages to participating in an overseas project?

- Did your experiences in the host country change your global perspectives? If they did, how?

- Did you observe any classes or teachers in your host country? If you did, what did you learn from that observation? How was your relationship with the teachers and students?

\section{Results}

The participant teachers stated that they have decided to go abroad on their own choice, because they have been curious about other countries. Their teaching experiences in abroad were their first international teaching experiences. According to the findings, four 
main themes emerged from the participant teachers' responses: 1. Learning Instructional Pedagogy, 2. Comparison of Countries, 3. Developing self and relation, and 4. Global Thinking.

\subsection{Learning Instructional Pedagogy}

Within an overseas project, it is expected that participants engage in all teacher-related functions of the school in the host nation. Therefore, participants observed the classroom, spent time with teachers, examined extra-curricular activities and taught to children. From these experiences, the participant teachers have said that they had learned various instructional methods including classroom management, how they access children, how they integrate subjects in their curriculum and how they use activities. For example, one of the participant teachers has stated:

By the nature of going to a new culture and seeing different ways of teaching practices or performs you learn new pedagogy, you learn new classroom management styles, teaching philosophies and potentially you understand why certain educational philosophy may work for specific context (Participant 1, 2014, personal communication).

The other one has claimed that "observing the classroom showed me different style of classroom managements; it demonstrated to me there was not one type of approach. Also it showed me how teachers chose their pedagogical strategies" (Participant 2, 2014, personal communication).

The participant teachers have noted differences in the instruction methodology. For instance, one of the participant teachers has expressed that "In England, they were using a portfolio to evaluate students, but it was not necessarily graded. The important point for them was to give qualified feedbacks to children" (Participant 3, 2014, personal communication).

In addition to learning about instructional methodologies, they had learned specific activities for specific courses. In relation to this issue, one of the participant teachers have said that:

I remembered that in one class, the teacher and her student had built a "time capsule" that was something kids take turn to go in and stand in to go back to a time in history. That was how they were teaching history. I thought it was a very clever and exciting activity that made the learning fun (Participant 4, 2014, personal communication).

The participant teachers' responses have obviously demonstrated that they have learned many new approaches and techniques of teaching. All four participants believe that overseas teaching experiences have made them more flexible teachers who can consider various teaching strategies and classroom management styles.

\subsection{Comparison of countries}

As a result of international studies, the participant teachers have a tendency to compare America with host nations. Schooling is the most frequently compared issue among the participants. The participant teachers have reflected that students in the host nation were encouraged to engage with the art, music, dance, and drama. For instance, one of the participant teachers- who went to Scotland- has said, "In Scotland students wore traditional clothing for festivals and they did special dance with special music. Read certain poems, they 
were keeping their culture alive" (Participant 1, 2014, personal communication). From their reflections, it seems like teachers and students are flexible and have more freedom in European countries than United States. One of the participant teachers has claimed:

Teaching in two countries is different. It took time to adjust to the condition. Here, education is based on the top-down approach and process driven curriculum. Teachers always explain what students should do at every steps of curriculum. In England, education was more-project driven, and children were not controlled by their teachers, they managed themselves (Participant 3, 2014, personal communication).

The other participant teacher- who went to Scotland- has said:

Teachers have more freedom to be creative there. That country also had high stakes testing but not as much as in the US. It was not intense as in the US. Here teachers are under pressure like principals walk through to make sure everybody is on same page (Participant 2, 2014, personal communication).

The other issue for comparison is the living condition in the two countries. Three participant teachers have made similar statements that people in Scotland and England enjoy their life. One of the participant teachers has asserted:

One thing I noticed going overseas, people enjoyed being in moment, being in present. They got together for dinners; they were hanging out and talking until feeling tired then they moved to home. Here, people are always looking at their watch like 'I need to go'(Participant 1, 2014, personal communication).

Two participant teachers have reflected that in England and in Scotland parents and families have good relationship with each other. The participant teacher, who went to England, has said, "Parents were creating parties, inviting teachers and they drank together. Here, there is a line between parents and teachers because of the professional life" (Participant 3, 2014, personal communication).

With the exception of one participant, three participant teachers have claimed that there was a less structure curriculum compared to the United States. They have felt like both teachers and students benefited from this less structure curriculum, which allows teachers, and students have more freedom in daily classroom.

\subsection{Developing self and relationships}

The responses of the participants seem to indicate that cultural immersion experiences helped them to grow in personal development. Referring to cultural immersion experiences, one of the participant teachers has expressed "It changes your identity to be open minded and culturally aware" (Participant 4, 2014, personal communication). Another participant teacher has claimed:

By nature of term, you are working cross-culturally. You are putting yourself out of your culture and into a new culture that means out of your comfort zone. It is going to force you to develop yourself or you are going to be overwhelmed and immediately fly back to US (Participant 2, 2014, personal communication).

Additionally, the participant teachers have made statements to the effect that study abroad helped them to develop awareness of possibilities and empathy. In this regard, one of the 
participant teachers said:

One of the things I learned from community experiences is that just the different dimension is possible for issues that I have not consider certain ways previously. Like in New Zealand I participated in special needs home, as a part of service project I was completing there. It demonstrated me how New Zealand treat special needs citizen and how they worked to provide best care for them. There were many interventions for special needs children. It was a different experience for me to see how people empathize and help special need children (Participant 4, 2014, personal communication).

Also one of the participant teachers has talked more about how relations with the host family and community helped him to socialize. He has explained:

If you live with a host family, you learn the culture a little bit more because you socialize and have extra feedback how to adapt yourself. If you are doing something incorrect that they, host families, might hopefully comfortable and confident enough with you to correct you and let you know 'by the way you do not want to do that because it is culturally offensive' or something along those lines' (Participant 1, 2014, personal communication).

In sum, all participant teachers have claimed that overseas experience was a beneficial opportunity for them to learn more about themselves and others. They have stated that people were embracing them and making them feel like insiders. They have had strong relationships with host families, host teachers, and students in the host nations.

\subsection{Global Thinking}

As a result of the nature of international experience, the participants not only learned about them and teaching, but they also increased their understanding of global concerns and issues. For example, one of participant teachers has commented:

By nature of going into a new cultural setting, there is gonna be a more global educational style, seeing how certain issues may have been taught in your home culture and seeing how issues are taught in this new culture (Participant 1, 2014, personal communication).

Within this global understanding, the participant teachers have made sense of the relations among the countries. One of participant teachers has stated:

What we do now in the United States is exactly what the United Kingdom did in the 80 s. It is important to say how countries influence each other. We have always been globalized via media, but if you have communicated with people via media or Internet, they are surface level connections. Through overseas experiences, you can embody the culture (Participant 3, 2014, personal communication).

Also the participants have asserted that they have very rich conversations with teachers in the host country about global issues. One of the participant teachers has said:

We have very rich discussions with teachers about culture, politics around the world. One of the things you realize that there are so many things to learn. If you are going to be a better global citizen, you have to continue educating yourself and reaching out the people (Participant 4, 2014, personal communication). 
In relation to globalization, the participants have claimed that media introduces Americans as very affluent persons who enjoy the life and have very comfortable living condition. Also, American movies show that people in the America are very good at technological skills. Therefore, the participants were faced with very interesting question in host countries. For instance, one student in England asks a question like "What kinds of technological skills does your wardrobe have", since this children saw in the movies that American people had multifunctional wardrobes.

\section{Discussion}

Based on the outcomes of this study, the participants have benefited positively as a result of overseas cultural immersion experiences. Participants express statements like

Every day I am really thankful that I had these experiences. It was the best decision I have ever made. My friend and I who were placed in same school, we are still talking about it. So many years later, 13 years later, we are still talking about it and I know we would speak until the day we die (Participant 1, 2014, personal communication).

The outcome of this study supports Wilson's theory (1993) at many levels. The participant teachers have acquired substantive knowledge about a host nation's culture, including instructional techniques, human relations, living condition, and culture. The participants have made many comparisons between the US to the host nation. Not surprisingly, the participants mostly compare the educational system of two countries, followed by the living condition of the two nations. The findings show that participants develop a perceptual understanding that includes global awareness, becoming more open-minded person, the development of empathy and understanding the importance of communication and feelings of an outsider. In particular, they have talked about how media plays a critical role in global process. When the literature has been examined, some researchers have found similar results in their studies (Vaughn, 2015).

The other major finding of this study is that participants' experiences help them to become a better person. They are aware of more possibilities than before. Also, the participants develop cross-cultural interpersonal relationships with the teachers and host families, and their connections with these people are still continuing. These findings are consistent with the results of Stachowski and Sparks (2007) who found that student teachers with having overseas cultural immersion experiences develop themselves in terms of personal and professional growth.

The only challenge the participant teachers have mentioned is language. The participants often talk about the challenge of trying to understand the conversation. Even if these participants had gone to English speaking countries, they claimed that people's English accents and dialogues were different and hard to understand. This finding is coherent with the results of Chisholm (1994) who found that language is very important to prepare teachers for multicultural classrooms.

\section{Conclusion}

As a first-hand experience, the cross-cultural experience helps the participants, as teachers, to gain a meaningful perspective on other cultures and it helps to be aware of their own place in the world. Living in a different culture encompasses the learning about language, history, tradition, family relations and all the surroundings of culture. 
The participants of this study reveal that overseas experience has value, and that especially for teachers, it is a very valuable experience. They have learned much about instructional methodology, how to access children, and various classroom management styles. When they share these new lessons, they also contribute to the education of those who are unable to go abroad. All of these new experiences are also valuable issues for teacher educators and teacher education programs, which may create opportunities for teachers to gain cross-cultural and overseas experience. The participants still see all challenges as very beneficial life experiences that enabled them to grow. They strongly recommend that everybody should participate in the same experience.

It is worth to mention that, even if this research reveals positive feedback about student experiences, there are several weaknesses and limitation. First of all, this research is a small size research so that the results are more specific to this group. Further study may be conducted to hear the voice of more teachers who went to other countries.

\section{References}

Barkhuizen, G. \& Feryok, A. (2006). Pre-service teachers' perceptions of a short-term international experience programme. Asia-Pacific Journal of Teacher Education, 34(1), 115-134.

Chisholm, I. M. (1994). Preparing teachers for muliticultural classrooms. The Journal of Educational Issues of Language Minority Students, 14, 43-68.

Cushner, K. (2007). The role of experience in the making of internationally-minded teachers. Teacher Education Quarterly, 34(1), 27-39.

Eisner, E. (1991). The enlightened eye: Qualitative inquiry and the enhancement of educational practice. Englewood Cliffs, NJ: Prentice- Hall.

Ference, R. A. \& Bell, S. (2004). A cross-cultural immersion in the US: Changing preservice teacher attitudes toward Latino ESOL students. Equity \& Excellence in Education, 37(4), 343-350.

Grant, C. A. (1992). Research and multicultural education: From the margins to mainstream. London: Falmer Press.

Ladson- Billings, G. (1994). The dream keepers: Successful teaching of African-American students. San Francisco: Jossey- Bass.

Lichtman, M. (2013). Qualitative research in education: A user's guide. Sage publications

McKay, J. W. \& Montgomery, J. (1995). Changes in perceptions: A comparison study of the experimental learning of international student teachers. Paper presented at the Annual Meeting of the American educational Research Associations, San Francisco, CA.

Merriam, S. B. (2009). Qualitative research: A guide to design and implementation. San Francisco, CA: Jossey-Bass.

Merryfield, M. M. (1991). Preparing American secondary social studies teachers to teach with a global perspective. A status report. Journal of Teacher Education, 42, 11-20.

Mertens, D. M. (2009). Research and evaluation in education and psychology: Integrating diversity with quantitative, qualitative, and mixed methods (3rd ed.). Thousand Oaks, CA: SAGE Publications, Inc.

O’Connor, K. \& Zeichner, K. (2011). Preparing US teachers for critical global education, Globalization, Societies and Education, 9(3-4), 521- 536.

Patton, M. L. (2010). Proposing empirical research: A guide to the fundamentals. Glendale, CA: Pyrczak Publishing. 
Pence, H. M. \& Macgillivray, I. K. (2008). The impact of an international field experience on preservice teachers. Teaching and Teacher Education, 24(1), 14-25.

Stachowski, L. L. \& Mahan, J. M. (1995). Learning from international field experiences. In G.A Slick (Ed.), Emerging trends in teacher preparation: The future of field experiences (pp.97-107). Thousand Oaks, CA: Corwin Press.

Stachowski, L. L. \& Sparks, T. (2007). Thirty years and 2,000 student teachers later: An overseas student teaching project that is popular, successful, and replicable. Teacher Education Quarterly, 115-132.

Taylor, S. J. \& Bogdan, R. (1998). Introduction to qualitative research (3rd Ed.). New York, NY: Wiley.

Vaughn, C. (2015). The self-perceived impact of an international immersion experience on the cultural competency and professional practice of recently graduated registered nurses. Graduate College Dissertations and Theses. Paper 379.

Willard-Holt, C. (2001). The impact of a short-term international experience for preservice teachers. Teaching and Teacher Education, 17, 505-517.

Wilson, A. H. (1982). Cross - cultural experiential learning for teachers. Theory Into Practice, 21(3), 184-192.

Wilson, A. H. (1993). Conversation partners: Helping students gain a global perspective through cross-cultural experiences. Theory Into Practice, 32, 21-26. 